\title{
防爆式空気圧ロボットの動特性解析と安定化法*
}

\author{
朝 倉俊 行*1, 国 慶 志*2, 高 野 宣也*2
}

\section{A Study on Dynamic Analyses of Explosion-Proof Pneumatic Robot and Its Stabilization}

\author{
Tosiyuki ASAKURA, Qingzhi GUO and Yosinari TAKANO
}

\begin{abstract}
This paper describes the development of an explosion-proof pneumatic robot for use in the chemical or oil industry. For such a robot, the electric part must be completely separated from the combustible gas. In our study, a pneumatic robot is designed in which the robot controller is linked with an actuator by a long pneumatic tube in order to prevent explosion. Then, the robot system is modeled as a nonlinear time-delay system as used in the aerodynamic analyses, and the validity of this model is confirmed through simulation and experimental studies. However, the robot manipulator will generate hunting due to the time lag of pneumatic pressure signals. Thus, a two-step PID controller is proposed, which not only prevents hunting but also reduces the steady state error to zero. The effectiveness of this PII) controller has been verified through simulation and experiments. Moreover, the stability margins for the pneumatic tube length are evaluated.
\end{abstract}

Key Words: Explosion Proof. Pneumatic Robot. Two-Step PID Controller. Nonlinear System, Time Lag, Friction Disturbance, Hunting, Steady-State

\section{1. 緒言}

ロボットの防爆性は化学工業, 塗装工業, 石油工業 等において可燃性, 危険性がある場合, 非常に重要な 仕様の一つである。しかし現在の電動式ロボットにお いてまだ本質的に安全防爆構造(I3G6)の対応が完全 には行われていない. 一方，古くは空気压による駆動 は炭坑機械を防爆することなどが発端となっており， 現在でもガスに対する防爆対策に空気压を用いている 例が多い(1)(2). 空気庄ロボットは電気式に比べ防爆性 に優れて㧈り，接触作業に扔ける衝突力の緩和や柔軟 な動作が叮能であるが,このことから従来の空気压機 器の欠点を緩和, 克服し, 安定な制御動作を維持する ことのできる空気仕:制御機器の開発, 実用化が望まれ ている.

本研究では防瑔性に優れた空気圧ロボットの開発を 目的とする。防爆対策としては，電気信号を処理する 電空変換器とロボットアームのアクチュエータとの間 を空気压管路によって接続するのが一般的である。し

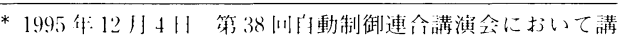

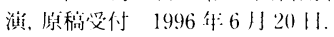

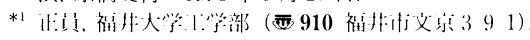

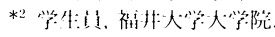

かし，管路が長くなると空気圧制御は一層難しくなる だけでなく，むだ時間によりアームに発振現象が生じ、 安定な特性を得ることは困難となる(3). また, 一般に 空気圧系が、摩擦力の影響を受けやすい等さまざまな 問題を抱えており, 高精度な制御性能を実現するため には制御手法に工夫が必要となる。

これまで, 空気圧サーボ系の研究は多くなされてい るが(4),このような防爆構造をもつ空気圧システムの 開発は十分に行われていない. そこで, 本研究では, まず防爆構造をもつ空気圧ロボットを試作し, 制御対 象の特性解析を行い, 本システムの動特性が非線形む だ時間システムとして表現されることを明らかにす る。これに基づいてこのような非線形むだ時間システ ムに生じる発振現象を防止するため, 簡便な安定化の ための 2 段階 PID 制御法を提案する. 本制御法はむ だ時間の同定誤差に対しても強いロバスト性をもち, また摩擦㧍よび負荷外乱に対しても定常偏差を限りな く零に近づけることができるという特徴ももつてい る.さらに実実験とシミュレーション実験により提案 した制御方式の有効性を確認し, 空気圧ロボット開発 の基礎資料を得る。 


\section{2. 防爆式空気圧ロボットの構成}

防爆構造をもつ 1 リンク空気圧ロボットの概略図を 図 1 に示す。ロボットアームの関節角度をリニアポテ ンショメータにより検出し, A/D変換ボードを通じ てコントローラであるコンピュータへフィードバック する.これに基づいてコンピュータ内で構成されたソ フトウェアサーボにより電空制御弁の操作量を決定 し, D/A 変換ボードを通じて電空変換器の空気圧を 変化させ,制御された空気圧信号が長いビニール管路 を経由してアクチュエータへ伝送され，アームの駆動 部の空気圧モー夕に変位を与える。

図 2 は制御系の実験装置を示す。ここで, 使用する 管路の内径は $d=6.0 \mathrm{~mm}$, 電空変換器は $\mathrm{SMC}$ (株) 製 のIT2031-32 型である. 入力圧力範囲は 0.55〜0.71 $\mathrm{MPa}$, 出力圧力は $0 \sim 0.51 \mathrm{MPa}$ である. 本実験装置 はレギュレータにより電空変換器への入力はすべて $0.6 \mathrm{MPa}$ の恒压動作で機能する。空気圧モー夕は $\mathrm{SMC}$ (株)製のベーンタイプの CRBUW 30 型で, 内部 容積は $20.2 \mathrm{~cm}^{3}$, 摇動角度は $0 \sim 270^{\circ}$, 使用圧力範囲 は $0.1 〜 0.99 \mathrm{MPa}$ である。

\section{3. 防爆式空気圧ロボットのモデル化}

防爆式空気压ロボットの動特性を解析するため, 空 気圧ロボットを図 3 のようにモデル化し, 各要素の伝 達特性を求め, 制御系の構造を決定する.

$3 \cdot 1$ 電空変換器 まずノズルフラッパ形電空変 換器の伝達関数 $G_{n}(s)$ は次式で与えられる(5).

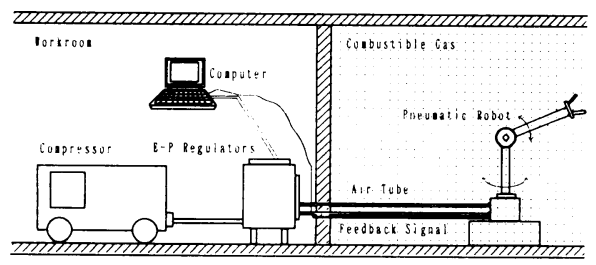

Fig. 1 Structure of explosion`proof pneumatic robot

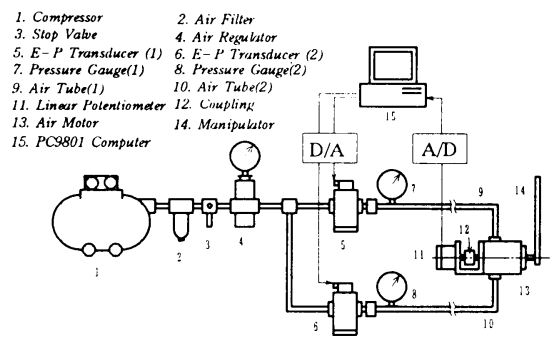

Fig. 2 Structure of experimental equipment

$$
G_{n}(s)=\frac{K_{n} \omega_{n}{ }^{2}}{s^{2}+2 \omega_{n} \rho_{n} s+\omega_{n}{ }^{2}}
$$

ここで, $\omega_{n}$ は電空変換器の固有拢動数, $\rho_{n}$ は減衰 係数, $K_{n}$ はグインである.

式(1)の各パラメータは, コンピュータからの人力 データと珐力センサにより測定した電空変換器の出力 データを用い，最小二乗法により推定した。推定值は 次のように得られた。

$$
\begin{aligned}
& K_{n}=0.508\left(\mathrm{kgf} / \mathrm{cm}^{2}\right) / \mathrm{v}, \quad \omega_{n}=8.63 \mathrm{rad} / \mathrm{s}, \\
& \rho_{n}=1.92 \ldots \ldots \ldots \ldots \ldots \ldots \ldots \ldots \ldots \ldots \ldots \ldots \ldots \ldots \ldots \ldots \ldots \ldots \ldots \ldots \ldots \ldots \ldots \ldots \ldots
\end{aligned}
$$

式( 2 )0パラメー夕をも一式( 1 )0夙波数心答とそ

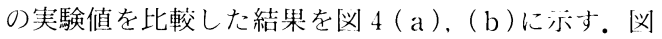
4 より実験値とシミュレーション結果はほぼ一致して おり, 得られた電空変換器のモデリングの有效性とパ ラメータ推定の妥当性を確認した。

$3 \cdot 2$ 空気圧管路空気圷管路の信号伝達特性に 関する研究は比較的多くなされているが(6)，ここでは、

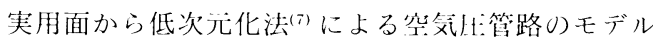
化を考える。

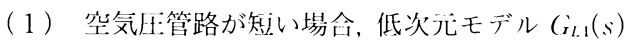
は二次遅れ系とむだ時間によって表される。

$$
G_{L 1}(s)=\frac{\omega_{L}^{2} e^{-L_{s}}}{s^{2}+2 \omega_{L} \rho_{L S}+\omega_{L}^{2}}
$$

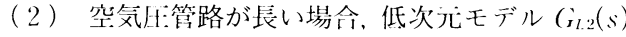
は一次遅れ系とむだ時間によって表される。

$$
G_{L 2}(s)=\frac{e^{-L s}}{T_{L s} s+1}
$$

ここで，Lは管路の長さによるむだ時間であり，( は固有周波数, $\rho_{L}$ は減衰係数， $T_{L}$ 壮時定数である。

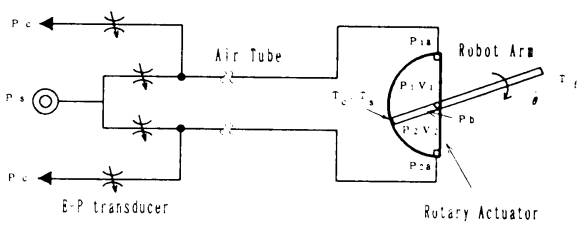

Fig. 3 Modelling of pneumatic robot
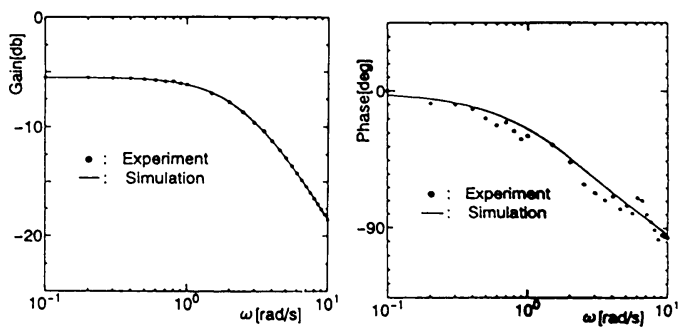

(a) Gain diagram

(b) Phase diagram

Fig. 4 Frequency characteristics 
Table 1 Estimated parameters of air tube

\begin{tabular}{|c|c|c|c|c|c|c|}
\hline $\mathrm{m}$ & 0.3 & 20 & 40 & 60 & 80 & 100 \\
\hline $\mathrm{T}_{\mathrm{L}[\mathrm{s}]}$ & - & 0.13 & 0.40 & 0.73 & 1.12 & 1.72 \\
\hline$\omega_{\mathrm{L}}$ & 21.3 & 18.9 & 9.84 & 13.3 & 13.9 & 9.70 \\
\hline$\rho_{\mathrm{L}}$ & 0.89 & 0.84 & 1.58 & 1.97 & 2.05 & 3.52 \\
\hline $\mathrm{L}[\mathrm{s}]$ & 0.01 & 0.06 & 0.12 & 0.23 & 0.38 & 0.56 \\
\hline
\end{tabular}

各パラメータの推定結果を表 1 に示す.

$3 \cdot 3$ 空気圧モータとロボットアーム 空気圧モ ータによるアームの運動方程式は次式で与えられる。

$$
J \ddot{\theta}+B \dot{\theta}=\left(P_{1}-P_{2}\right) A_{m}-\left(T_{c}+T_{f}\right)
$$

ここで $\theta$ はアームの角変位, $J$ はアームの慣性モ一メ ント, $B$ は粘性摩擦係数, $A_{m}$ は吐き出し容積, $P_{1}, P_{2}$ は各チャンバの空気圧力, $T_{c}, T_{f}$ は運動摩擦損失卜ル クおよび負荷トルクである.

\section{また, モー夕の始動条件式は}

$$
\left(P_{1}-P_{2}\right) A_{m} \geqq T_{s}+T_{f}
$$

で与えられる。 $T_{s}$ は静止摩擦トルクである。

次にチャンバ内の流量, 圧力, 変位の関係を調べる. チャンバ内の状態変化を断熱変化と仮定すると, 気体 状態方程式とエネルギー平衡式は次のように表され る.

$$
\begin{aligned}
& W_{1}=\frac{1}{\chi R T}\left(V_{1} \frac{d P_{1}}{d t}+x P_{1} \frac{d V_{1}}{d t}\right) \\
& W_{2}=\frac{1}{\chi R T}\left(V_{2} \frac{d P_{2}}{d t}+\chi P_{2} \frac{d V_{2}}{d t}\right)
\end{aligned}
$$

ここで $W_{1}, W_{2}$ は各チャンバへの質量流量, $x$ は比熱 比, $R$ はガス定数, $T$ はチャンバ内の絶対温度, $V_{1}$, $V_{2}$ は各チャンバの体積である。アームがロータリア クチュエータの中央に位置している状態を基準状態と 考え, 式( 7 ), (8)をこの状態の周りで線形化する と.

$$
\begin{aligned}
& \Delta W_{1}=\frac{1}{x R T}\left\{\left(\frac{d P_{1}}{d t}\right)_{0} \Delta V_{1}+\left(V_{1}\right)_{0} \frac{d\left(\Delta P_{1}\right)}{d t}\right\} \\
& +\frac{1}{\chi R T}\left\{\chi\left(P_{1}\right)_{0} \frac{d\left(\Delta V_{1}\right)}{d t}+\chi\left(\frac{d V_{1}}{d t}\right)_{0} \Delta P_{1}\right\} \\
& \Delta W_{2}=\frac{1}{x R T}\left\{\left(\frac{d P_{2}}{d t}\right)_{0} \Delta V_{2}+\left(V_{2}\right)_{0} \frac{d\left(\Delta P_{2}\right)}{d t}\right\} \\
& +\frac{1}{\chi R T}\left\{\chi\left(P_{2}\right)_{0} \frac{d\left(\Delta V_{2}\right)}{d t}+\chi\left(\frac{d V_{2}}{d t}\right)_{0} \Delta P_{2}\right\}
\end{aligned}
$$

となる.ここで, 初期值を

$$
\begin{aligned}
& \left(V_{1}\right)_{0}=\left(V_{2}\right)_{0}=V_{0}, \quad\left(P_{1}\right)_{0}=\left(P_{2}\right)_{0}=P_{0} \quad \cdots \cdots(11) \\
& \left(\frac{d V_{1}}{d t}\right)_{0}=\left(\frac{d V_{2}}{d t}\right)_{0}=0, \quad\left(\frac{d P_{1}}{d t}\right)_{0}=\left(\frac{d P_{2}}{d t}\right)_{0}=0
\end{aligned}
$$

のように設定する。また，体積の変化について

$$
\frac{d\left(\Delta V_{1}\right)}{d t}=\left(-\frac{d\left(\Delta V_{2}\right)}{d t}\right)=A_{m} \frac{d(\Delta \theta)}{d t}
$$

が得られる。各チャンバ内の圧力変化量は

$$
\Delta P_{1}=-\Delta P_{2}=\Delta P_{b}
$$

のように設定する. 式 ( 9$)$ ～(14)から

$$
\Delta W_{1}-\Delta W_{2}=\frac{2}{\chi R T}\left\{V_{0} \frac{d\left(\Delta P_{b}\right)}{d t}+\chi P_{0} A_{m} \frac{d(\Delta \theta)}{d t}\right\}
$$

が得られる、また, モー夕の流量圧力特性は次のよう に設定する。

$$
W_{1}=W_{1}\left(P_{1 a}\right), \quad W_{2}=W_{2}\left(P_{2 a}\right)
$$

ただし, $P_{1 a}, P_{2 a}$ はモー夕の出入口の圧力である. 式 (16)を線形化すると

$$
\Delta W_{1}=\left(\frac{d W_{1}}{d P_{1 a}}\right) \Delta P_{1 a}, \quad \Delta W_{2}=\left(\frac{d W_{2}}{d P_{2 a}}\right) \Delta P_{2 a}
$$

となる.ここで

$$
\begin{aligned}
& \left(\frac{d W_{1}}{d P_{1 a}}\right)_{0}=\left(\frac{d W_{2}}{d P_{2 a}}\right)_{0}=W_{a 0} \\
& \Delta P_{1 a}=-\Delta P_{2 a}=\Delta P_{a}
\end{aligned}
$$

のように設定する。式(17)〜 (19) から次の関係が得ら れる。

$$
\Delta W_{1}-\Delta W_{2}=2 W_{a 0} \Delta P_{a}
$$

式（5），(15)，(20)はラプラス変換により

$$
\begin{aligned}
& J s^{2} \theta(s)+B s \theta(s)=2 A_{m} \Delta P_{b}(s)+D(s) \\
& \Delta W_{1}(s)-\Delta W_{2}(s)=\frac{2}{\chi R T}\left(V_{0} \Delta P_{b}(s)\right. \\
& \left.+\chi P_{0} A_{m} s \theta(s)\right) \\
& \Delta W_{1}(s)-\Delta W_{2}(s)=2 W_{a 0} \Delta P_{a}(s) \cdot
\end{aligned}
$$

のように変換される。ここで

$$
D(s)=L\left[-\left(T_{c}+T_{f}\right)\right] \cdots
$$

である. 式(21)〜 (23)を整理して, 空気圧モータと口 ボットアームの入出力の圧力変化からアームの角変位 までの伝達関数は次のように表される。

$$
\theta(s)=G_{m}(s)\left[\Delta P_{a}(s)+d(s)\right] \cdots
$$
ここで,

$$
\begin{aligned}
& G_{m}(s)=\frac{K_{m} \omega_{m}{ }^{2}}{s\left(s^{2}+2 \omega_{m} \rho_{m} s+\omega_{m}{ }^{2}\right)} \\
& d(s)=\frac{s D(s)}{K_{m} J \omega_{m}{ }^{2}} \ldots \ldots \ldots \ldots \ldots \ldots \ldots \ldots \ldots \ldots \ldots \ldots
\end{aligned}
$$

である.各係数は

$$
\begin{aligned}
& K_{m}=\frac{R T W_{a 0}}{P_{0} A_{m}}, \quad \omega_{m}=A_{m} \sqrt{\frac{2 \chi P_{0}}{V_{0} J}}, \\
& \rho_{m}=\frac{B}{2 A_{m}} \sqrt{\frac{V_{0}}{2 \chi P_{0} J}} \cdots \cdots \cdots \cdots \cdots \cdots \cdots
\end{aligned}
$$

で与えられる。ここで， $P_{0}$ および $V_{0}$ は基準状態での チャンバ内での圧力と体積を表す。 


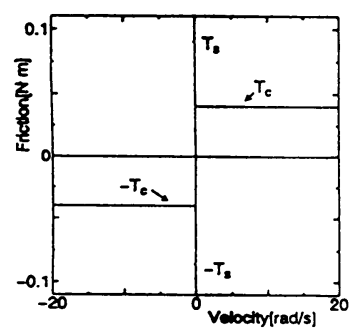

(a) Ideal model

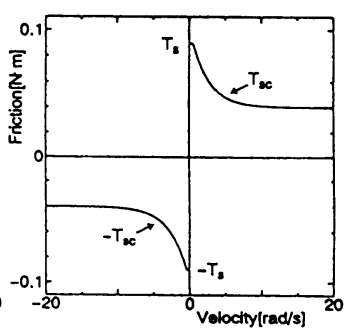

(b) Real model
Fig. 5 Modelling of friction

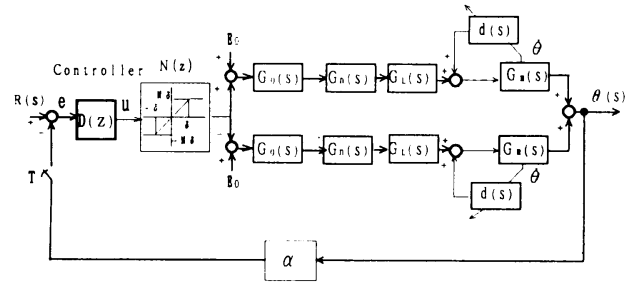

Fig. 6 Block diagram of explosion-proof pneumatic robot

\section{$3 \cdot 4$ 固体摩擦モデル 固体摩擦には一般に動き} 始めるときに生じる静摩擦と, 速度が零より大きい場 合にほほ速度に無関係な一定値をとる動摩擦があり, 静摩擦は動摩擦よりも大きいことが知られている．摩 擦外乱のある力学系の解析には, 一定の動摩擦だけを 扱ったものや, 図 5 (a)のように理想化近似と呼ばれ る静摩擦と動摩擦を不連続に近似したもの, 図 5 ( b ) のように静摩擦から動摩擦までの負こう配を考慮して これを指数関数や双曲線関数で表したものなどが用い られている(8). ここで用いる固体摩擦の速度特性(固 体摩擦と滑り速度の関係)を次のような指数関数を含 む関数で表されるものとして考え ${ }^{(9)}$, 実験結果より次 式で表されるものとする.

$$
T_{s c}=0.06 \cdot \exp (-0.4 \cdot|\dot{\theta}|)+0.04 \& T_{s c} \leqq 0.09
$$

$3 \cdot 5$ シミュレーション実験 以上の解析から本 システムのブロック線図は図 6 のように表現される。 ただし, 伝達関数 $G_{0}(s)$ は零次ホールドの連続関数で, 次式で表される(10).

$$
G_{0}(s)=\frac{1-e^{-h s}}{s}
$$

ここで, 図60モデルを用いたシミュレーション実 験と実実験との比較検討を行う。シミュレーション実 験に用いるおもなパラメー夕は表 2 に示す. また, 実 実験で用いたコントローラ $D(z)$ はPI 制御とし, 各

\begin{tabular}{|c|c|}
\hline$\kappa \quad 1.4$ & $\mathrm{~K} n \quad 0.05(\mathrm{MPa} / \mathrm{V})$ \\
\hline $289(\mathrm{~K})$ & $8.63(\mathrm{rad} / \mathrm{s})$ \\
\hline B $\quad 1.3 \times 10^{-3}\left(\mathrm{~kg} \cdot \mathrm{m}^{-2} / \mathrm{s}\right)$ & $\rho$ \\
\hline 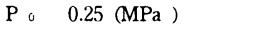 & $21.3(\mathrm{rad} / \mathrm{s})$ \\
\hline $\mathrm{V}_{0} \quad 1.01 \times 10^{4}\left(\mathrm{~mm}^{3}\right)$ & $\rho L$ \\
\hline $\mathrm{J} \quad 4.67 \times 10^{-3}\left(\mathrm{~kg} \cdot \mathrm{m}^{2}\right)$ & $0.01(\mathrm{~s})$ \\
\hline $20(\mathrm{~mm})$ & $\mathrm{T}=\quad 0.40(\mathrm{~s})$ \\
\hline $\mathrm{W} .03 .0 \times 10^{3}$ & $L=0.12(\mathrm{~s})$ \\
\hline $\begin{array}{lll}R & 287 & (\mathrm{~J} / \mathrm{kg} \cdot \mathrm{K})\end{array}$ & \\
\hline
\end{tabular}

Table 2 System parameters

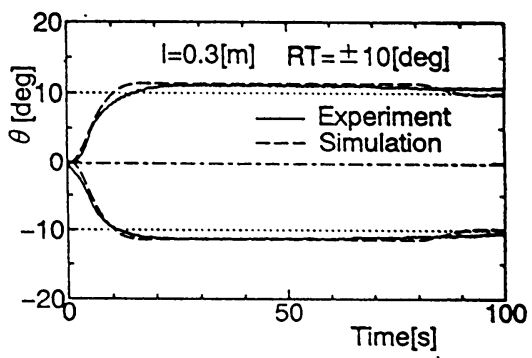

Fig. 7 Simulation and experiment (1)

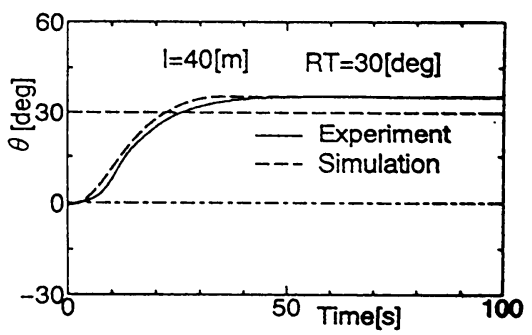

Fig. 8 Simulation and experiment (2)

パラメータは $K_{p}=0.5, T_{i}=10$, サンプリング周期は $0.02 \mathrm{~s}$ とした。結果を図 7,8 に示す。図 7 の場合, 管路の長さは $0.3 \mathrm{~m}$, 目標值は土 $10^{\circ}$ とし, 図 8 の場 合, 管路の長さは $40 \mathrm{~m}$, 目標值は $30^{\circ}$ とした。結果よ り, シミュレーション実験と実験は定量的・定性的に ほぼ一致することが確認され, システムモデルの妥当 性が検証された。

\section{2 段階 PID 制御の構成}

図 6 に示すシステムはむだ時間および摩擦外乱の影 響を受け，安定な制御をするには，むだ時間補償およ び摩擦外乱補償をしなければならない。従来, PID 制 御を適用したとき, 定常特性の改善を基本的に積分動 作によりおこなっている。しかし，非線形の影響が大 きい空気压制御系では，操作量が有限であるため制御 
哭差が累積する。ロボットアームが目標近傍に達する と、動作は遅くなるので, 制御入力と摩擦力が釣合う. その場合, 非線形摩擦力は動作状態によって変化し, また, 動摩擦は最大静止摩擦よりかなり小さいので, ロボットアームは目標值近傍で微小な振動を生じ, 制 御系の応答が遅くなる.ゲインを高めて応答速度を早 めようとするとむだ時間により発振現象が生じる。こ のような問題を解决するため, 本論文ではゲインを制 御誤差に忍じて切り換える 2 段階 PID 制御方式を提 案する。

$4 \cdot 12$ 段階 PID 制御法 2 段階 PID 制御方式 とは，通常は制御系を安定させるように適当な制御ゲ インで動作させ, 高い制御感度が必要な位置, すなわ ち, 静止直前後における摩擦力の変化や静止摩擦力の 影響を受ける場所では, ゲインが高くなるよう切換え て強いブレーキ機構の機能を果たすような制御を行 い, 目標位置に一致させ, 十分な応答精度を確保しよ うとするものである。

図 6 における PID コントローラ $D(z)$ の入出力関 係は次のように記述される。

$$
\Delta u_{n}=K_{p 1}\left\{\Delta e_{n}+\frac{h}{T_{i}} e_{n}+\frac{T_{d}}{h}\left(\Delta e_{n}-\Delta e_{n-1}\right)\right\}
$$

ここで, $\Delta u_{n}=u_{n}-u_{n-1}, \Delta e_{n}=e_{n}-e_{n-1}$ とし, $h$ は サンプリング周期, $u_{n}$ は出力, $e_{n}$ は誤差信号であり, 次式で定義される。

$$
e_{n}(z)=R_{n}(z)-\theta_{n}(z)
$$

式(32)の誤差信号が大きいときにはオーバシュート 抢よび発振を避けるためゲインを小さくし, 誤差信号 が十分小さくなったときは制御精度を上げるためゲイ ンを高くするように切り換える. 切り換え制御則を式 (33)に示寸.ゲインを切り換えてからの誤差信号はほ ぼ零で, 積分動作の影響が少なくなり,また, 時間が 十分経過すると微少な振動が生じ，このような悪影響 を除去するため，D制御が付加される。

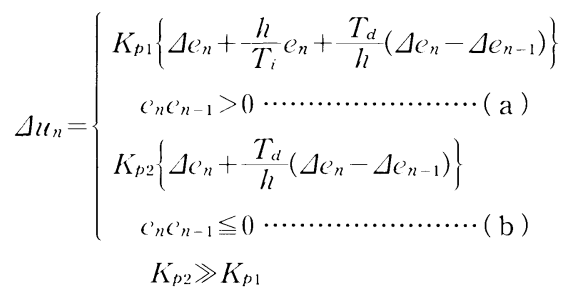

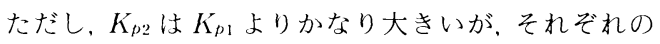
値は実験により決定される。

$4 \cdot 2$ 制御器の特性戍 6 0)モデルを用い, 提案

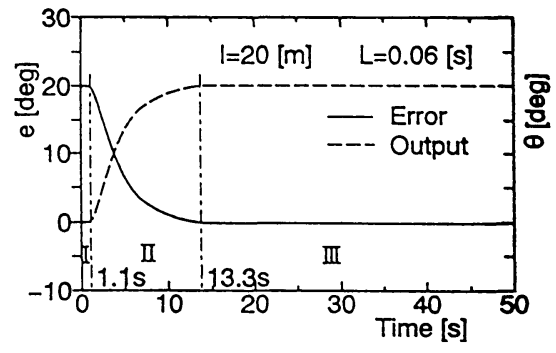

Fig. 9 Input to controller

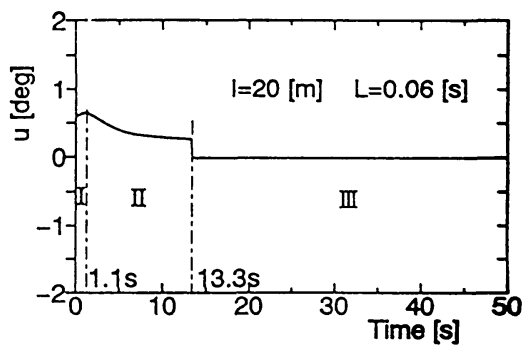

Fig. 10 Output from controller

した 2 段階 PID 制御器の特性についてシミュレーシ ヨン実験を行い, 制御器への入力と出力の関係を調べ た. 2 段階 PID 制御器 $D(z)$ の各パラメータは,

$K_{p 1}=0.5, \quad K_{p 2}=2.5, \quad T_{i}=10 \mathrm{~s}, \quad T_{d}=0.2 \mathrm{~s}$

のように設定した。また，制御対象の各パラメータは 表 2 に示す。管路の長さは $20 \mathrm{~m}$, 目標角度は $20 \mathrm{deg}$ である.シミュレーション結果を図 9 および図 10 に 示す.その結果より，ゲインを $K_{p 1}$ にしても，むだ時 間および式（6)の始動条件より領域 $\mathrm{I}(0 \leqq t \leqq 1.1 s)$ で は，ロボットアームの駆動力が静止摩擦力を越えない 限り動かない. 領域 II $(1.1 s \leqq t \leqq 13.3 s)$ では，ロボッ トアームが初期値からだんだん目標値に近付き, 13.3 秒経過した時刻で $e_{n} e_{n-1} \leqq 0$ を満たしたとき，制御則 が式(33)の（a）から（b)に切り換わる. 領域 III $(t>$ $13.3 s)$ では, 制御ゲインが $K_{p 2}$ で, 制御系が定常状態 に保持されていることを示す．管路の長さおよび目標 值を変えてもいずれも同様な結果が得られた.シミュ レーション実験結果より目標值近傍で目標值と操作量 の間の誤差信号はほぼ零であるので, ゲインを大きく しても安定性が崩れない特徵をもっている.また，こ の手法により, 制御目標の追従特性を改善し, 外乱の 除去を図るとともに，定常偏差を限りなく零に近づけ ることができる。 


\section{5. 実験結果および考察}

提案した 2 段階 PID 位置決め制御方式の有効性を 検討するため, 図 2 の装置を用いて実験を行い, 安定 性と過渡特性および定常偏差を考察する.さらに, 本 制御法の安定範囲を検討する。

$5 \cdot 1$ 応答特性 図 11,12 は従来のPID 制御で のステップ応答である.システムの発振現象を避ける ために, 制御器のゲインを小さくしなければならな い.しかし，ゲインが小さくなると，図に示すように 過渡特性の整定時間が長くなり，定常応答を得るのは 困難となる。一方，提案した 2 段階 PID 制御法を用 いた場合の応答実験の結果を図 13 に示す。ただし, 制御器のパラメータは式(34)のように設定した。また 管路の長さは $20 \mathrm{~m}$, 目標值は $\pm 10, \pm 20, \pm 30, \pm 40$, $\pm 50^{\circ}$ に設定した。図 11,12 に示すように従来の PID 制御器では良好な定常応答を得るのは困難であるが, 図 13 の結果より, 本実験で用いた制御系については $\pm 0.246 \mathrm{deg}$ 程度の位置決め精度が実現でき, 本制御 法の有効性が確認された。しかし図 13 に示すように 立ち上がり時間が長く過渡特性がよくない, その原因 は安定化のため制御ゲインを小さく抑えなければなら ないことと, 実験装置に使用した空気圧モー夕の出力 トルクも小さいことによる.これらの問題に対して, 出力トルクの大きいモー夕を使用し, さらに摩擦外乱 の補償をあらかじめ加えることにより実験装置を改良

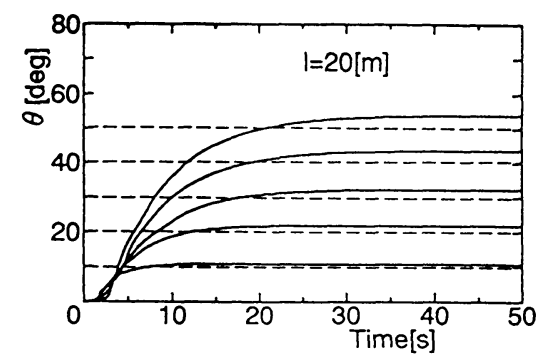

Fig. 11 Dynamic characteristics by PID (1)

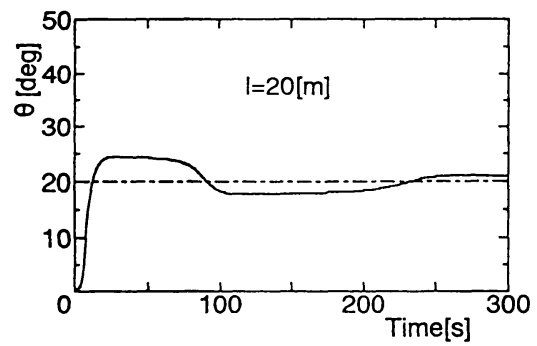

Fig. 12 Dynamic characteristics by PID (2)
し過渡特性を改善する研究を進めている。

$5 \cdot 22$ 段階 PID 制御の安定範囲学だ時間を含 む防爆式空気圧ロボットシステムに対して従来の PID 制御を適用した場合，ゲイン $K_{p}$ を大きくしたり， 空気圧管路が長くなるとシステムに発振現象が生じ る. 発振現象の一例を図 14 および 15 に示す. 図中の 縦軸はロボットアーム関節角度変位, 横軸は時間であ る. 図 14 は管路が $20 \mathrm{~m}$ の場合, 目標値を $50 \mathrm{deg}$ と したときの発振現象を示す， $K_{p}=0.50$ の場合安定で あるが, $K_{p}=0.55$ とわずかに変化しても発振現象が 生じる.一方, 管路が $100 \mathrm{~m}$ に長くなると, ロボット アームは図 15 に示すように常時大きな周期の発振現 象を生じる。

次に，管路の長さを変化させ，従来のPID 制御と 2 段階 PID 制御をした場合のゲインによる安定限界を 実実験で調べる。パラメータは， $T_{i}=10 \mathrm{~s}, T_{d}=0.2 \mathrm{~s}$,

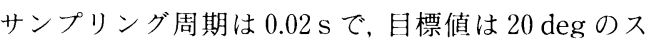

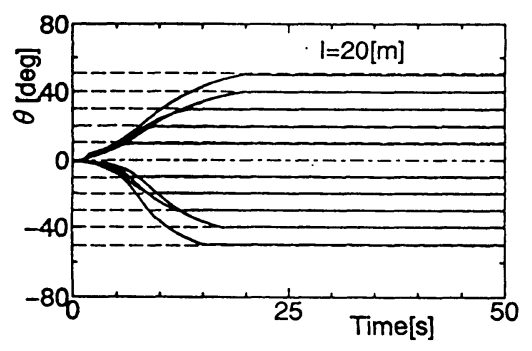

Fig. 13 Step response by two-step PID

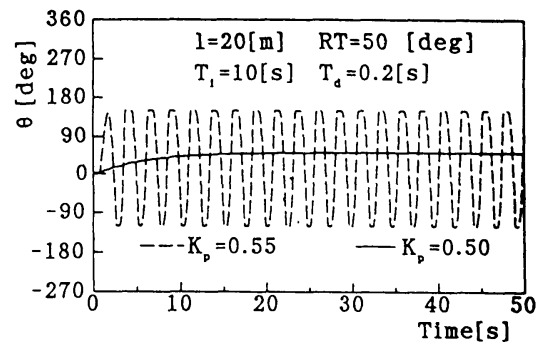

Fig. 14 Hunting due to control gain

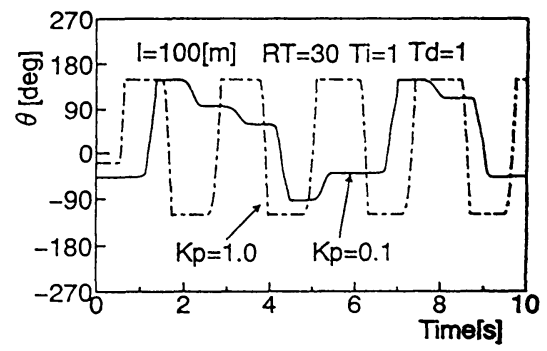

Fig. 15 Hunting due to time delay 


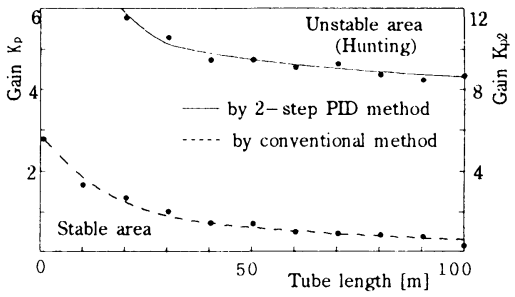

Fig. 16 Stability region by 2 -step PID method

テップ入力とした. その結果を図 16 に示す. 図 16 中 の丸印点は実験值であり, 安定限界を示す。実線は 2 段階 PID 制御においての切り換えたゲイン $K_{p 2}$, 破線 は従来の PID ゲイン $K_{p}$ を表す．その結果から， 2 段 階 PID 制御でゲインを切り換えた場合の安定領域が 従来の PID 制御の場合と比較して拡大していること がわかる．また，目標値が変化した場合についても 2 段階 PID 制御の安定範囲に影響しないことがわかる.

\section{6. 結 論}

本研究では, 防爆式空気圧ロボットの開発を目的と し, 防爆のため, 電気信号を処理する電空変換器と口 ボットアームのアクチュエータの間を長い空気圧管路 によって接続する方法を用い, 実システムを構成し た。まず最初に,このようなシステムは非線形むだ時 間システムとして表現されるので，この場合の動特性 の解析を行った．特に，制御性能に及ぼす駆動部の摩 擦特性を従来の理想モデルとは異なり, 静摩擦力から 動摩擦力までの負こう配を考慮して表現することによ り, 制御対象としての空気圧ロボットの動特性を表す
数学モデルを確立し, その妥当性をシミュレーション 実験と実実験より確認した。次に，むだ時間による発 振現象の防止と制御特性を改善するため，2段階 PID 制御方式を提案し, シミュレーション実験と実実験の 両面からその特性を検討した。本制御法は大きいむだ 時間が存在しても安定性を確保し, かつ摩擦外乱を除 去する効果が顕著であり, 位置决め制御精度向上に極 めて有効であることを確認した。

本論文では主に位置決め精度について考察したが， 今後摩擦外乱の補償をあらかじめ加えた工夫を施せ ば, 制御性能はさらに向上すると考える.

\section{文献}

（1）段野勝・朝倉俊行・島田貢明・部谷尚道, 電空弁ポジシ ヨナの動特性の改善(第 2 報)，機論，55-512，B（1988）, 1124-1128.

（2）長谷川健介, 制御理論 II， (1987)，131，昭晃堂.

（3）朝倉俊行・徐涁・段野勝, 電空弁ポジショナにおける発 振現象の防止とロバス卜安定性, 機論, 57-541, C (1991), 82-88.

（4）山藤和男，空気圧アクチュエータのロボット制御への心 用, 日本ロボット学会誌, 19-4(1991)，498-501.

（5）朝倉俊行・大諳宏之・段野勝, 電空弁ポジショナの動特 性の改善(第 3 報)，機論, 57-533, C (1991), 88-93.

(6) Schuder, C. B. and Binder, R. C., The Response of Transmission Lines to Step Input, Trans. ASME. Series D, 18(1959), 578-586.

（7）香川利治・北川能 - 真田一志・竹中俊夫, 空気圧管路の 動特性を表示する低次元モデルに関する研究, 計測自動 制御学会論文集, 21-9(1985)，953-959.

(8) Halling, J., トライボロジ, (1984), 15, 近代化学社.

（9）清水友治・猪岡光，カルマンフィル夕による固体摩擦の 推定(第 2 報)，機論, 54-502, C (1988)，1345-1349.

（10）荒木光彦, ディジタル制御理論入門, (1991), 38, システム 制御情報学会編. 